\title{
Problematika Film Alih Media: Dari Transformasi Hingga Kontroversi
}

\author{
Acep Iwan Saidi, Dyah Gayatri Puspitasari \\ KK Ilmu-Ilmu Desain dan Budaya Visual FSRD-ITB-Bandung \\ Jl. Ganesa 10 Bandung; School of Design Universitas Bina Nusantara-Jakarta, \\ Jl. Kyai H. Syahdan No.09 Palmerah-Jakarta Barat \\ Tlp.081222202040, 0818111062 \\ acepiwan@fsrd.itb.ac.id, dyah@binus.edu
}

\begin{abstract}
This article contains a study of film adaptation from a literature media (novel) into audio-visual media (film). This research is a case study of Perempuan Berkalung Sorban film by Hanung Bramantyo, which was adapted from a novel with the same title that was written by Abidah el-Khalieqy. By combining a text analysis method from Thomas Leittch, Mathew T. Jones' film adaptation theory and the result of interview to confirm the text analysis, this research produced some interesting findings. The research verified that the adaptation's process does not merely focus on technical issue in media adaptation (from novel to film), but also focuses on another aspects that will involve the audience i.e. a fact that text and dialogue become references that will be appreciated by audience. As a result, there were excessive distortions and deviations on the text that were created by the film maker caused a bias interpretation. Audiences no longer interpreted the film as a visual text objectively. Instead, they would think about certain prejudice against the film maker. In film adaptation, certain tendencies of film maker are easy to be predicted by audience. This fact has caused film adaptation becomes controversial easily.
\end{abstract}

Keywords: Media Adaptation, Transformation, Opposition, Controversy

\begin{abstract}
ABSTRAK
Artikel ini berisi kajian tentang alih media, yakni dari media verbal sastra (novel) kemedia visual film. Kajian ini berupa studi kasus terhadap film Perempuan Berkalung Sorban karya Hanung Bramantyo, yang merupakan adaptasi dari novel dengan judul sama karya Abidah el-Khalieqy. Dengan menggunakan metode gabungan, yakni analisis teks yang berdasar pada teori adaptasi film dari Thomas Leittch, Mathew T. Jones, dan wawancara tertulis untuk mengkonfirmasi analisis teks tadi, kajian ini menemukan hal menarik, yakni alih media bukan sekedar persoalan teknis pemindahan media, melainkan juga pemindahan yang menimbulkan efek-efek tertentu bagi penonton. Apresiasi penonton dilandasi kesadaran bahwa terdapat teks lain yang menjadi rujukan film bersangkutan. Akibatnya, distorsi dan deviasi yang terlalu jauh yang dilakukan sutradara atas teks sumber berpotensi mengakibatkan bias pemahaman. Penonton tidak lagi memaknai film sebagai teks visual secara objektif, tetapi juga dibarengi praduga-praduga tertentu terhadap sutradara. Pada genre film alih media, tendensi tertentu dari sutradara mudah dibaca penonton. Fakta ini mengakibatkan film sangat rentan menimbulkan kontroversi.

Kata Kunci: alih media, transformasi, oposisi, kontroversi
\end{abstract}

Kata Kunci: Alih Media, Transformasi, Oposisi, Kontroversi, 


\section{PENDAHULUAN}

Alih media, khususnya dari media sastra ke film,bukanlah fenomena baru. Dalam sejarah film, alih media sudah dimulai pada masa awal kelahiran genre film itu sendiri, yakni ketika masih pada zaman film bisu sutradara Austria Erich Von Stroheim mengadaptasi novel McTeague karya Frank Norris (1899) menjadi film berjudul Greed Di Indonesia, fenomena alih media sastra ke film juga telah berlangsung lama, yakni sejak awal dekade 1960-an. Pada 1962, Umar Ismail menciptakan film berjudul Perempuan di Sarang Penyamun. Film ini diadaptasi dari novel dengan judul sama yang ditulis Sutan Takdir Alisyahbana pada tahun 1930.

Akhir dasawarsa 80-an hingga akhir 90-an, dunia perfilman Indonesia mengalami kemunduran. Di samping langkanya film yang berkualitas, posisi film nasional juga didesak oleh film-film impor. Baru pada awal tahun 2000-an, film nasional kembali menampakkan gairahnya. Dan yang menarik, salah satu yang menandai bangkitnya gairah tersebut adalah produksi film alih media dari karya sastra. Film-film yang dibuat berdasarkan karya sastra tersebut diminati banyak penonton. Film Laskar Pelangi (2008) yang diangkat dari novel dengan judul yang sama karya Andrea Herata, misalnya, ditonton oleh 4.631 .841 orang. Dari sisi jumlah penonton, pencapaian ini merupakan yang tertinggi dalam sejarah film Indonesia. Pada tahun yang sama, film Ayat-Ayat Cinta, yang diangkat dari novel berjudul sama karya Habiburrachman El Shierazy, ditonton oleh 3.7000 .000 orang (Saidi, 2011, hlm. 14). Dari sisi produksi, ledakan (booming) produksi film alih media juga terus meningkat. Situs Indosinema.com (2016), misalnya, mencatat bahwa pada tahun 2013 terdapat 18 film alih media. Pada tahun 2014 jumlah ini meningkat menjadi 21 film. Walhasil, alih media menjadi fenomena yang menyemarakkan dunia perfilman nasional Indonesia. Berikut adalah tabel beberapa film produksi alih media yang populer hingga tahun 2015.

Mengapa produksi film alih media menjadi marak hingga menandai bangkitnya kembali film nasional di Indonesia? Dalam Focus Group Discussion yang penulis lakukan dalam rangka riset film adaptasi pada tahun 2015 di Bandung ditemukan beberapa jawaban. Pertama, penulisan skenario film berdasarkan novel dimungkinkan lebih mudah dibandingkan dengan menyusun skenario yang utuh mengingat, paling tidak, pada novel tentu telah tercipta alur, karakterisasi, pemilihan seting, dan lain-lain. Kedua, film hasil alih media dari karya sastra lebih mudah meraih penonton mengingat umumnya para penonton film tersebut merupakan pembaca novelnya. Ketiga, secara teoretik esensi semua genre karya seni sesungguhnya bersumber kepada hal yang sama. Suzanne K. Langer (2006) mengatakan bahwa semua seni memiliki esensi yang sama, hanya berbeda dalam jenis dan model ekspresinya.

Namun demikian, sejauh ini belum terdapat kajian mendalam tentang produksi film alih media tersebut. Padahal, di samping kefenomenalannya, film hasil alih media bukan berarti tanpa masalah. Jika pun pendapat Langer soal esensi seni di atas dapat 
Tabel 1: Daftar Contoh Film Indonesia Berbasis Alih Media

Sumber: Saidi (2011: 14), dengan beberapa penambahan oleh penulis dari berbagai sumber

\begin{tabular}{|c|c|c|c|c|c|}
\hline NO & JUDUL FILM & SUTRADARA & THN & JUDUL NOVEL & PENGARANG \\
\hline 1. & $\begin{array}{l}\text { Surga Yang Tak } \\
\text { Dirindukan }\end{array}$ & Kuntz Agus & 2015 & $\begin{array}{l}\text { Surga Yang Tak } \\
\text { Dirindukan }\end{array}$ & Asma Nadia \\
\hline 2. & Supernova & Ertha J Shahab & 2014 & Supernova & Dewi Lestari \\
\hline 3. & Adriana & Fajar Nugros & 2013 & $\begin{array}{c}\text { Adriana: Labirin } \\
\text { Cinta di Kilometer } \\
\text { Nol" }\end{array}$ & Fajar Nugros \\
\hline 4. & $\begin{array}{l}99 \text { Cahaya di } \\
\text { Langit Eropa }\end{array}$ & $\begin{array}{c}\text { Guntur } \\
\text { Suharyanto }\end{array}$ & 2013 & $\begin{array}{l}99 \text { Cahaya di } \\
\text { Langit Eropa }\end{array}$ & $\begin{array}{c}\text { Hanum Salsabila } \\
\text { Rais }\end{array}$ \\
\hline 5. & $\begin{array}{l}\text { Laskar Pelangi 2: } \\
\text { Endensor }\end{array}$ & Benni Setiawan & 2013 & $\begin{array}{c}\text { Laskar Pelangi 2: } \\
\text { Endensor }\end{array}$ & Andrea Herata \\
\hline 6. & $\begin{array}{l}\text { Tenggelamnya } \\
\text { Kapal Vanderwijk }\end{array}$ & Sunni Soraya & 2013 & $\begin{array}{c}\text { Tenggelamnya } \\
\text { Kapal Van Derwijk }\end{array}$ & Hamka \\
\hline 7. & Negeri 5 Menara & $\begin{array}{l}\text { Affandi Abdul } \\
\text { Rachman }\end{array}$ & 2012 & Negeri 5 Menara & Ahmad Fuadi \\
\hline 8. & $5 \mathrm{Cm}$ & $\begin{array}{c}\text { Rizal } \\
\text { Mantovani }\end{array}$ & 2012 & $5 \mathrm{Cm}$ & Donny Dirgantoro \\
\hline 9. & Sang Penari & Ifa Isfansyah & 2011 & $\begin{array}{c}\text { Ronggeng Dukuh } \\
\text { Paruk }\end{array}$ & Ahmad Tohari \\
\hline 10. & $\begin{array}{l}\text { Ketika Cinta } \\
\text { Bertasbih 1-2 }\end{array}$ & Chaerul Umam & 2009 & $\begin{array}{l}\text { Ketika Cinta } \\
\text { Bertasbih 1-2 }\end{array}$ & $\begin{array}{l}\text { Habiburrachman } \\
\text { El Shierazy }\end{array}$ \\
\hline 11. & $\begin{array}{l}\text { Perempuan } \\
\text { Berkalung Sorban }\end{array}$ & $\begin{array}{l}\text { Hanung } \\
\text { Bramantyo }\end{array}$ & 2009 & $\begin{array}{c}\text { Perempuan } \\
\text { Berkalung Sorban }\end{array}$ & $\begin{array}{l}\text { Abidah el- } \\
\text { Khalieqy }\end{array}$ \\
\hline 12. & Laskar Pelangi & Riri Reza & 2008 & Laskar Pelangi & Andrea Herata \\
\hline 13 & Ayat-ayat Cinta & $\begin{array}{l}\text { Hanung } \\
\text { Bramantyo }\end{array}$ & 2008 & Ayat-ayat Cinta & $\begin{array}{l}\text { Habiburrachman } \\
\text { El Shierazy }\end{array}$ \\
\hline 14. & Gie & Riri Reza & 2005 & $\begin{array}{l}\text { Buku Catatan } \\
\text { Harian Seorang } \\
\text { Demonstran }\end{array}$ & Soe Hok Gie \\
\hline 15. & $\begin{array}{l}\text { Eiffel...I'm in } \\
\text { Love }\end{array}$ & Nasry Cheppy & 2003 & Eiffel...I'm in Love & $\begin{array}{l}\text { Rachmania } \\
\text { Arunita }\end{array}$ \\
\hline
\end{tabular}

disetujui, perbedaan tiap genre sebenarnya bukan hanya pada soal atribut, tetapi juga pada hakikat yang menjadi basis karakternya. Hakikat novel (prosa), misalnya, adalah peristiwa, sedangkan hakikat film adalah gerak, termasuk di dalamnya gerak kamera. Keduanya tentu tidak bisa disamakan. Oleh sebab itu, pengalihmediaan karya sastra ke film sering mengakibatkan perbedaan yang substansial. Perubahan bukan hanya terjadi pada genre-nya, tetapi juga pada berbagai elemen yang terkandung di dalamnya.
Berdasarkan situasi demikian, penulis melakukan penelitian terhadapnya. Paling tidak penulis melihat tiga permasalahan yang menarik dikaji. Pertama, bagaimana pergeseran yang terjadi pada alih media, baik aspek tematik maupun bentuk? Kedua, bagaimana pergeseran tersebut dapat berpengaruh kepada penerimaan penonton? Ketiga, Bagaimana hubungan antara pergeseran dalam alih media dengan kontroversi yang terjadi di masyarakat? 
Mengingat jumlah film alih media sangat banyak, tidak mungkin penulis melakukan pengkajian terhadap keseluruhannya. Oleh sebab itu, dilakukan seleksi terhadap film yang diyakini dapat merepresentasikan permasalahan tersebut. Untuk itu, penulis memilih film Perempuan Berkalung Sorban (selanjutnya disingkat PBKS) karya Hanung Bramantyo sebagai kasus. Film ini dipilih dengan tiga alasan sebagai berikut. Pertama, PBKS adalah film alih media dari novel yang tidak memiliki reputasi menonjol dalam konstelasi sastra Indonesia. Hal ini di luar kebiasaan sebab pada umumnya novel yang difilmkan hampir selalu merupakan karya yang telah populer di kalangan pembaca sastra. Sebut saja, misalnya, novel Siti Nurbaya, Belenggu, Laskar Pelangi, dan Ayat-Ayat Cinta. Film-film yang diangkat dari novel populer biasanya juga mengalami sukses yang sama, bahkan bisa lebih sukses dari novelnya. Kedua, meskipun tidak berdasarkan novel yang pouler, film $P B K S$ ternyata mendapat sambutan baik dari penonton. Film ini juga mendapat berbagai penghargaan, antara lain, memenangkan satu kategori pemeran Pembantu Pria terbaik pada Festival Film Indonesia (2009) dan pada beberapa peran pada Indonesia Movies Award tahun 2009, yakni Pemeran Utama Wanita Terbaik, Pemeran Utama Wanita Terfavorit, dan Pemeran Pembantu Pria Terfavorit. Ketiga, di samping kesuksesannya, PBKS juga menimbulkan kontroversi, khususnya di kalangan tokoh Islam tertentu. Beberapa pihak, termasuk Majelis Ulama Indonesia (MUI) sempat melarang peredaran film ini karena dianggap mendiskreditkan Islam, khususnya dunia pesantren. "Pesantren dalam film tersebut digambarkan sangat tidak sesuai dengan realitas, sebagai institusi pendidikan agama yang kolot, anti perubahan dan tertutup" demikian dikatakan Sekretaris Jenderal Pengurus Besar Nahdhatul Ulama Indonesia, Endang Turmudi (2015).

\section{METODE}

Analisis terhadap film alih media tersebut dilakukan dengan cara menggabungkan dua metode, yakni metode analisis teks dan wawancara tertulis di lapangan. Analisis teks dilakukan untuk mengidentifikasi pergeseranpergeseran yang terjadi pada teks visual film yang dirujukkan kepada novel sebagai teks sumbernya. Sementara itu, wawancara lapangan terhadap sejumlah respondens dimaksudkan untuk memverifikasi hasil analisis teks tadi. Upaya ini penting mengingat penelitian juga bertujuan untuk mengetahui sebatas mana pandangan publik terhadap film alih media, dalam hal ini secara khusus film yang menjadi objek penelitian. Untuk hal ini dipilih 50 orang penonton film sekaligus pembaca novelnya, yang secara kualitatif dianggap representatif sebagai responden. Salah satu ukurannya, responden yang dipilih terdiri atas pembaca yang berpredikat pelajar dan mahasiswa.

Pada tataran analisis teks, film hasil dari alih media (novel ke film) diposisikan sebagai karya yang bersumber pada persilangan teks. Merujuk kepada Genette (dalam Leitch, 2007) setidaknya terdapat lima hal ketika sebuah 
teks lahir dari teks yang lain atau ketika persilangan teks terjadi. Kelima hal itu adalah intertextuality, paratextuality, metatextuality, hypertextuality danarchitextuality. Berdasarkan hal tersebut Leitch (2007) mengembangkan perspektifnya mengenai film adaptasi. Leitch antara lain mengemukakan bahwa tidak semua film adaptasi bersifat equal. Dengan merujuk kepada Geoffrey Wagner, Leitch (2007: 93) menyebut tiga tipe transisi dari fiksi ke film. Ia menulis:

"...three types of "transition of fiction into film": transportation, in wihich a novel is given directly on the screen, with a minimum of apparent interference"; commentary (alternatively "re-emphasis or restructure"), in which an original is taken and either purposely or inadvertently altered in some respect; and analogy, "a fairly considerable departure for the sake of making another work of art" (Leitch, 2007, hal. 93).

("...tiga tipe transisi dari karya fiksi ke film": transportasi, yakni narasi dalam novel yang dikirim (ditransfer) langsung ke dalam layar dengan seminimal mungkin perubahan; komentar (terkomentari), yakni penciptaan kembali atau restrukturisasi, sebuah transisi dengan beberapa perubahan, baik disengaja ataupun tidak; analogi, yakni transisi dengan perubahan besar yang memungkinkan terciptanya karya lain (berbeda dengan novel)"

Leitch (2007) selanjutnya menyebut beberapa kata kunci terkait proses pengalihmediaan teks verbal kaya sastra (novel) ke film. Kata kunci yang pertama adalah kompresi (compression). Kompresi atau penyingkatan (perasan) terjadi sebab tidak mungkin durasi film bisa dibuat sepanjang kisah di dalam novel, terutama juga tidak mungkin memindahkan semuanya menjadi gambar. "Three hundred-page novels", kata Leitch, "cannot be adapted to feuture length films without a great deal of systematic elision and omission". Waktu penceritaan film, bagaimanapun, jauh lebih pendek dari novel. Jika 200 halaman novel masih dapat dibaca dalam fleksibilitas waktu sampai dua hari, misalnya, rata-rata durasi film hanya dua jam.

Kata kunci kedua adalah ekspansi (expansion). Ini adalah hal sebaliknya dari kompresi. Film dapat merupakan sebuah karya perluasan dari sebuah cerita pendek. Dalam perluasan, sutradara dapat melakukannya hingga terjadi pertentangan dengan kisah dalam cerita pendek itu sendiri. Namun, membuat film adaptasi dengan cara memperluas kisah cerita pendek memang jarang terjadi. Biasanya hanya dilakukan jika kisah dalam cerita pendek sangat menarik dan karena itu sangat populer di kalangan pembaca. Leitch memberi contoh kasus ini pada film The Killers (1946) yang diadapatasi dari cerita pendek karya Hemingway yang ditulis tahun 1927.

Ketiga adalah koreksi (correction). Pada film-film adaptasi tertentu, seperti film adaptasi dari karya-karya Shakespeare, koreksi terjadi karena beberapa hal, misalnya karena sesuatu dianggap tidak ada pada karya aslinya. Karena kepentingan tertentu, menurut Leitch (2007) film-film Holywood 
yang diadaptasi dari karya sastra sering juga melakukan koreksi terhadap teks sumbernya.

Updating adalah kata kunci keempat. Karena perbedaan waktu penciptaan, filmfilm yang diadaptasi dari novel yang ditulis dalam kurun waktu lama sebelum penciptaan filmnya, biasanya mengalami updating. Hal ini dilakukan juga dengan mempertimbangkan target audiens. Updating biasa dilakukan pada aspek seting, kostum, dan lainlain. Bagaimanapun, karya-karya klasik Shakespeare, misalnya, dalam beberapa hal harus dikontekstualisasi ketika ditampilkan di hadapat masyarakat kontemporer, karena perbedaan zaman juga membedakan faktor sensibilitas masyarakatnya.

Kelima adalah superimposition. Dalam konteks penciptaan film, istilah superimposisi dapat diartikan sebagai penempatan gambar di atas gambar. Hal ini biasanya dilakukan untuk menambahkan efek gambar secara keseluruhan, tapi sering juga untuk menyembunyikan sesuatu, seperti menempelkan potret wajah yang berbeda di atas yang asli. Melampaui pengertian ini, Leitch (2007) menjelaskan bahwa pembuatan film adaptasi sangat rentan dari berbagai ekspresi, pesanan, dan berbagai pengaruh dari luar yang menyebabkan film tersebut menjadi tidak cepat dikenali sebagai sebuah teks yang berhubungan secara langsung dengan karya yang diadaptasinya.

Sejauh yang dapat penulis pahami, beberapa istilah kunci yang dikemukakan Leitch di atas berada pada level dasar yang bersifat umum tentang proses yang terjadi dalam adaptasi. Oleh sebab itu, masih perlu rujukan lain yang harus didiskusikan untuk memasuki tataran yang lebih operasional. Di sini penulis merujuk kepada (dalam Mc Ferlaine, 1996, hlm. 105-1007) yang mengatakan bahwa terdapat dua fungsi yang perlu dipahami, yaitu fungsi distribusi dan fungsi integrasi. Fungsi distribusi dibentuk dari rangkaian peristiwa yang berurutan. Fungsi ini terdiri atas dua bagian utama, yakni fungsi kardinal dan fungsi katalisator. Fungsi kardinal adalah peristiwa inti cerita yang merupakan poin penting dalam narasi. Sedangkan katalisator merupakan peristiwa kecil atau cerita pendukung yang mendukung dan melengkapi fungsi kardinal. Katalisator dapat ditranslasi sampai dengan batasan tertentu sedangkan fungsi kardinal ditransfer secara langsung ke dalam media adaptasi.

Sedangkan fungsi integrasi adalah fungsi yang menghasilkan unsur psikologis yang terbentuk dari suatu narasi. Unsur psikologis pada fungsi integrasi antara lain membentuk karakter para tokoh dan menciptakan atmosfer dan mood cerita. Fungsi integrasi tidak dapat diubah secara langsung dari satu media ke media yang lain, karena suasana psikologis yang terbentuk pada tiap media didapat dengan cara yang berbeda pula. Konflik batin tokoh dalam novel tentu digambarkan melalui deskripsi, dialog, atau perilaku tertentu pada tokoh. Sedangkan dalam film, sutradara memanfaatkan teknik sinematografi untuk mendapatkan efek psikologis dan mood tertentu sesuai dengan tujuan yang ingin dicapai.

Secara umum, Jones (2008, hlm. 115-116) menjelaskan beberapa hal yang biasa terjadi 
atau dilakukan oleh sutradara dalam membuat film adaptasi, baik dalam fungsi distribusi maupun integrasi. Pada fungsi distribusi, menurutnya biasa terjadi seleksi, kondensasi, dan reorganisasi. Seleksi adalah proses memilih hal yang memungkinkan untuk diadaptasi. Hal ini terjadi karena tidak semua fungsi dalam cerita bisa ditransformasikan ke dalam film. Kondensasi adalah proses yang lebih teknis setelah seleksi. Pengurangan dan penambahan tokoh atau karakter, misalnya, terjadi pada proses ini. Hal ini terjadi karena untuk penyesuaian durasi, narasi, dan lainlain. Bagian lain dari kondensasi adalah abriging atau penyingkatan fungsi utama narasi. Di samping penyingkatan, terjadi juga eliminasi (penghilangan). Fungsi katalisator narasi yang terlalu jauh dengan fungsi kardinal dalam novel, di dalam film biasanya dihilangkan. Terakhir adalah reorganisasi, yakni menyusun ulang bagian-bagian yang telah dipilih dalam seleksi dan kondensasi. Selanjutnya proses adaptasi dalam fungsi integrasi. Di dalam fungsi ini, menurut Jones (2008, hlm. 116), terjadi apa yang disebut translasi, yakni sebuah proses penyesuaian hal-hal di balik struktur, antara film adaptasi dengan teks sumbernya. Di sini, film adaptasi hendaknya tetap mempertahankan jiwa teks sumbernya. Untuk hal ini, translasi memberi ruang untuk melakukan manipulasi sehingga atmosfer pada film adaptasi serupa dengan media sumbernya. Di dalam proses translasi bisa dilakukan aktualisasi dan juga penyesuaian sesuai konvensi film adaptasi itu sendiri.

\section{HASIL DAN PEMBAHASAN}

\section{Sinopsis Film}

Film $P B K S$ berkisah tentang seorang perempuan bernama Annisa, sejak kanakkanak hingga berumah tangga. Annisa lahir dan dibesarkan di lingkungan pesantren yang dipimpin ayahnya, yakni Pesantren Al-Huda yang terletak di sebuah daerah pedalaman Jawa Tengah. Di lingkungan itu, sejak kecil Annisa hidup dalam konflik. Annisa merasa diperlakukan tidak adil oleh keluarganya, terutama oleh ayahnya. Annisa selalu dibelenggu. Berbeda dengan kedua kakak laki-lakinya yang bisa berperilaku bebas.

Konflik tersebut lantas berkembang ke persoalan agama, yakni tentang berbagai peraturan Islam yang ketat untuk kaum perempuan. Pesantren yang diasuh oleh ayah Annisa sendiri merupakan pesantren khusus anak perempuan. Dengan demikian, pesantren ini merupakan lembaga yang dipenuhi ajaran mengenai berbagai aturan dan pembatasan tentang perempuan, yang arahnya tertuju pada satu titik, yakni perempuan harus tunduk kepada laki-laki.

Sejak kecil Annisa memberontak terhadap ajaran tersebut. Satu-satunya orang yang mengerti Annisa adalah Khudori, paman dari pihak ibunya. Karena itu pula, diam-diam Annisa mencintai Khudori. Demikian juga Khudori, mecintai Annisa. Namun, Khudori harus pergi melanjutkan studinya ke Kairo. Annisa pun menjadi sangat kesepian dan menderita. Kenyataan paling pahit adalah ketika ia dinikahkan dengan laki-laki pilihan orang tuanya, Syamsudin. 
Harapan Annisa bangkit kembali ketika Khudori pulang dari Kairo. Mereka pun kembali menjalin hubungan. Hubungan ini kemudian diketahui Syamsudin sehingga pada suatu kesempatan Syamsudin menuduh mereka telah berzinah. Akibatnya, Khudori diusir dari pesantren dan Annisa pergi ke Yogyakarta, menemui temannya di sana, dan menjadi mahasiswa di sebuah uaniversitas.

Di Yogyakarta, selain kuliah Annisa juga aktif menulis di media massa. Di samping itu, Annisa bekerja di sebuah LSM yang mengadvokasi perempuan (istri) yang menjadi korban kekerasan dalam rumah tangga. Khudori, yang ternyata juga bekerja di Yogyakarta sebagai dosen, menemui Annisa. Mereka akhirnya menikah dan hidup berbahagia.

Namun, hal itu tidak berlangsung lama. Annisa mendapat musibah yang membuatnya sangat terguncang, yakni meninggalnya Khudori karena kecelakaan saat mengendarai motor dalam perjalanan menuju Yogyakarta dari rumah mertuanya. Annisa pun hidup dengan anak tunggalnya.

\section{Transformasi Tematik}

Merujuk kepada model adaptasi yang dikemukakan Ferlane (1996, hlm. 1005-107) yang juga dielaborasi T. Jones (2008, hlm 115-116) tentang fungsi dalam film adaptasi, khususnya fungsi kardinal, sebagaimana telah diuraikan sebelumnya, film PBKS memiliki lima fungsi utama, yakni kisah tokoh utama pada masa kanak-kanak dan remaja di lingkungan keluarganya, masa pernikahan pertama, masa kuliah di Yogyakarta, masa pernikahan kedua, dan masa setelah suaminya meninggal.

Secara garis besar, fungsi kardinal tematik dalam film tersebut tidak menunjukkan adanya distorsi yang berarti jika diacukan kepada novel sebagai teks sumbernya. Inti cerita atau tema, baik dalam film maupun novel, adalah perjuangan seorang tokoh perempuan bernama Annisa dalam memperjuangkan haknya sebagai perempuan secara sosial di tengah-tengah diskriminasi tradisi dan ajaran agama yang berpihak kepada laki-laki. Tampak dengan eksplisit bahwa film dan juga novel $P B K S$ berada dalam bingkai ideologi feminis (feminisme). Ajaran agama yang kolot yang dimanifestasikan melalui praktik pelajaran di pesantren tradisional Al-Huda tampak hanya menjadi latar untuk dioperasikannya ideologi tersebut.

Akibatnya, PBKS, baik sebagai film maupun novel, lebih menyerupai sebuah essay panjang. Pada film, suara sutradara tampak sangat dominan nyaris pada seluruh elemen film. Karakter Annisa kecil yang keras, ayah yang otoriter, sikap ustad yang kolot, perilaku Syamsudin yang liar dalam hubungan seksual, dan lain-lain cenderung artifisial. Perhatikan kalimat yang diucapkan Annisa kecil dalam dialog dengan orang tua dan kedua kakaknya sebagai berikut:

- Annisa : Saya ingin belajar naik kuda!

- Umi (Ibu) : Jangan bicara sambil makan, tidak baik.

- Annisa :Itu, Mas Rizal aja boleh. Kenapa Nisa nggak boleh?

- Abi (Ayah) : Karena kamu perempuan 


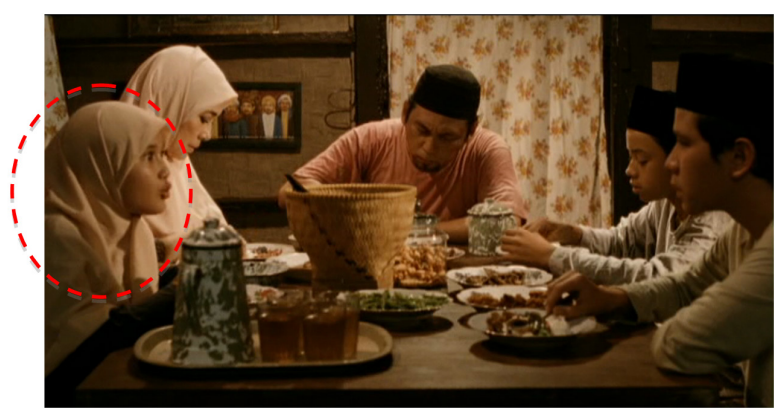

Gambar 1 : Adegan Annisa (wajah dilingkari) yang sedang memprotes kepada orang tua dan kedua kakaknya yang bersikap diskriminatif terhadapnya (Sumber :film PBKS, di-capture oleh penulis)

- Reza : Iya, kamu perempuan, nggak pantes!

- Annisa : Terus kenapa? Aisyah istri Nabi, Putri Budur, Hindun binti Athaba, mereka naik kuda dan memimpin pasukan!

Secara visual, ucapan tersebut dilontarkan Annisa kecil dalam gestur yang tampak seperti orang dewasa. Dengan kata lain, Annisa kecil mengucapkan kalimat orang dewasa yang dihapalnya dari teks (skenario) dengan gerak tubuh yang diarahkan sutradara.

Situasi demikian, sekali lagi, berbanding lurus dengan yang terdapat pada novel. Karakter artifisial Annisa dalam film bisa dikatakan sama persis dengan apa yang terjadi pada novel. Sudut pandang "aku-an" yang dipilih pengarang dalam $P B K S$ sangat kuat terasa sebagai suara pengarang. Dengan kata lain, narator $P B K S$ adalah pengarang. Ucapanucapan yang keluar dari mulut Annisa-yang dinarasikan oleh "aku" narator-merupakan rangkaian gagasan pengarang.

Di dalam film hal itu sebenarnya sedikit tertolong oleh kemampuan akting pemainnya, Revalina S Temat, yang memerankan tokoh Annisa (yang sudah dewasa). Revalina menggantikan (melanjutkan) Nasya Abigail sebagai pemeran Annisa yang masih anakanak. Kemampuan akting Revalina yang bagus, dalam banyak hal, telah mencairkan gagasan-tekstual yang diterjemahkan sutradara dari teks sumber.

\section{Dari Deviasi ke Penciptaan Narasi Baru}

Jika secara tematik film $P B K S$ merupakan pemindahan gagasan yang utuh dari novel sebagai teks sumbernya, secara bentuk tidak demikian. Pada lapis ini ditemukan berbagai pergeseran yang menyebabkan keduanya menjadi berbeda. Tentu saja, pergeseran utama terletak pada mediumnya, yakni medium verbal (bahasa verbal) pada karya sastra ke medium visual (bahasa visual) karya film. Perubahan medium ini pertama-tama menyebabkan bertransformasinya imaji visual karya sastra ke teks visual sebagai realitas film. Pada karya sastra, penggambaran mengenai tokoh, latar, dan objek lain pada hakikatnya tervisualisasi menjadi objek visual di kepala pembaca (imaji visual yang muncul setelah membaca). Sedangkan pada film, objek visual tersebut terletak di luar imaji penonton. Dengan kata lain, objek hadir secara konkret sebagai teks visual di luar diri penonton.

Selanjutnya, di dalam proses penciptaan film sudah pasti kru film itu sendiri(terutama sutradara) yang mentransformasi teks verbal ke dalam teks visual. Merujuk kepada semiotika Umberto Eco (1979) transformasi ini dapat diartikan sebagai memproduksi tanda (encoding). Proses ini sangat memungkinkankan terjadinya deviasi sampai pada titik terjauh. Dalam film $P B K S$, pemilihan pemeran (casting) oleh sutradara 


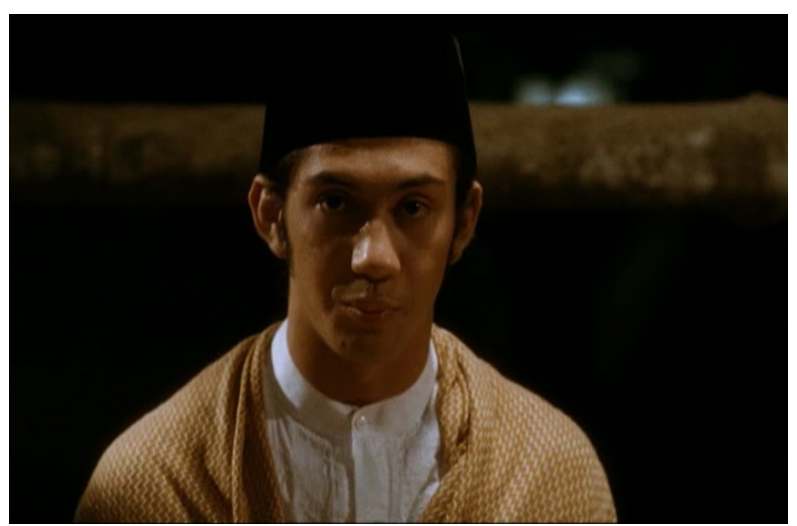

Gambar 2 : Sosok Syamsudin.

(Sumber : film PBKS, di-capture oleh penulis)

juga menunjukkan hal itu. Perhatikan pemeran antagonis Syamsudin pada gambar 2.

Sebagaimana tampak, secara visual sosok pemeran di atas memiliki tatapan mata yang teduh dan cenderung lembut. Hal ini berbeda, bahkan bisa dikatakan bertolak belakang, dengan deskripsi pada novel. Pada novel, Syamsudin digambarkan narator sebagai sosok yang, di samping liar dan beringas, juga jelek dan menjijikan, apalagi ketika ia sedang melakukan hubungan seksual dengan istrinya. Perhatikan kutipan berikut:

“Dan ketika ia menengok ke kiri atau ke kanan di antara tidurnya, setetes air liur berwarna kekuningkuningan meleleh dari mulutnya. Baunya membuatku mual ingin muntah. Jika sebuah mimpi buruk mendatangi tidurnya, ia akan menggeliat dan kakinya yang besar kasar dengan kuku-kuku hitamnya akan menyepak badanku atau kakiku dengan keras sambil mulutnya mengeluarkan geraman seperti harimau kelaparan" (Khalieqi, 2001, hlm. 100).

Selanjutnya, pada lapis struktur, film PBKS menunjukkan beberapa bagian yang berbeda dari novel PBKS. Perbedaan tersebut terjadi hingga pada titik ekstrem. Tabel 2 berikut menunjukkan beberapa fakta visual film yang berbeda dengan fakta teks-verbal di dalam novel.

Deviasi dalam alih media sangat dimungkinkan karena tuntutan film sebagai genre yang memang berbeda dengan karya sastra. Pada kasus pemilihan pemeran sebagai tafsir sutradara atas tokoh antagonis di atas, misalnya, deviasi dapat dipahami sebagai tuntutan film. Namun, bagaimanapun hal itu tetap merujuk kepada teks sumber sehingga dengan demikian deviasi tetap bisa dikatakan sebagai representasi. Merujuk kepada Abrams (1980, hlm. 31), dalam konteks alih media, film adalah cermin dari novel yang berposisi sebagai realitas yang dirujuknya, di situ, film menjadi cermin novel.

Namun, halnya berbeda dengan adeganadegan dalam film yang tidak terdapat pada teks sumber sebagaimana data pada tabel 2 . Dalam kasus ini, apa yang terdapat di dalam film tidak bisa dikatakan sebagai representasi peristiwa pada novel. Sekali lagi, fakta visual dalam film sedemikian memang merupakan hak dan wewenang sutradara, namun pada batas terjauh film tersebut menjadi berdiri sendiri. Di dalam $P B K S$, fakta visual semacam ini memang tidak dominan. Namun, ia tetap saja memiliki pengaruh yang signifikan terhadap nuansa pemaknaan cerita. Ia seolah menciptakan narasi baru. Hal ini bukan sebatas terbentuknya ketidaksetaraan (equal) antara film dan novel sebagaimana dikatakan Leitch (2007, hlm. 97), melainkan telah menciptakan masalah spesifik tersendiri.Dari penelitian yang kami lakukan, dalam film 
Tabel 2 : . Adegan dalam film yang tidak terdapat rujukannya pada novel Tabel dibuat oleh penulis

\begin{tabular}{l} 
PERISTIWA \\
\hline Adegan pembuka: perempuan \\
dengan bertutup kepala \\
sorban dan mengendarai kuda
\end{tabular}

Annisa kecil ditegur ibunya karena bermain di pantai bersama kedua kakaknya

Adegan penghukuman dan hujatan massa terhadap Annisa dan Khudori yang dituduh berzinah. Massa yg dirpovokasi Syamsudin menghujat Anissa \& Khudori. Peristiwa ini juga yg menyebabkan Annisa dan Syamsuddin bercerai.

Annisa menemui temannya di tempat kostnya di Yogyakarta. Teman Annisa ternyata sudah tidak memakai jilbab dan dengan bebas memasukkan teman laki-lakinya ke kamar kost.

Aktivitas Annisa yang bekerja di sebuah LSM yang menangani kasus KDRT.

Annisa pergi ke pantai setelah malamnya melakukan adegan suami-istri dengan seuaminya, Khudori. Hubungan seksual yg pertama kali bias dinikmati Annisa, setelah mengalami trauma Syamsudin.
TEKS SUMBER

Tidak terdapat pada novel. Novel dibuka dengan deskripsi sebuah kampung di lereng pegunungan (hal. 1)

Di dalam novel tidak ada narasi dan deskripsi tentang pantai, yang ada adalah tentang kampung di lereng pegunungan (hal. 1)

Tidak terdapat pada novel. Dalam novel, perceraian dilakukan secara normal, melalui perwakilan dan musyawarah dua keluarga (hal.177-186)

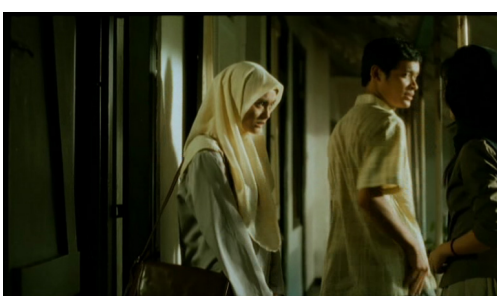

Tidak ada di dalam teks. Di dalam novel, Annisa pergi ke Yogyakarta dan diterima di sebuah perguruan tinggi, dan memilih jurusan filsafat (hal. 198).

Tidak ada di dalam teks. Di dalam novel, aktivitas Annisa

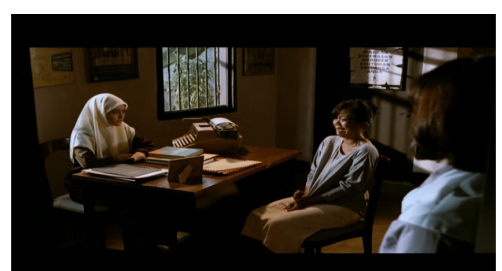
hanya sebagai Ibu Rumah Tangga, tidak diceritakan pekerjaannya yang lain. Bersama teman-temanya Annisa memang banyak bercerita tentang hubungan seks, suami-istri, dan soal gender, tapi tidak dalam kapasitasnya sebagai aktivis (hal. 221-235)

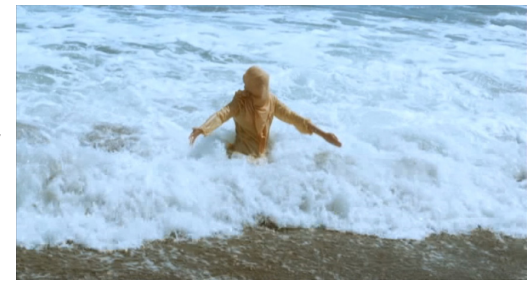

Di dalam novel, setelah malamnya berhubungan suami istri, paginya Annisa hanya bangun kesiangan. Mereka kemudian mandi. Annisa kemudian menemui teman-temannya dan bergosip tentang hubungan suami-istri (hal. 220-211) 
Khudori mengalami kecelakaan lalulintas dan meninggal. Tidak ada rekayasa apapun dalam kecelakaan ini (murni kecelakaan lalulintas)

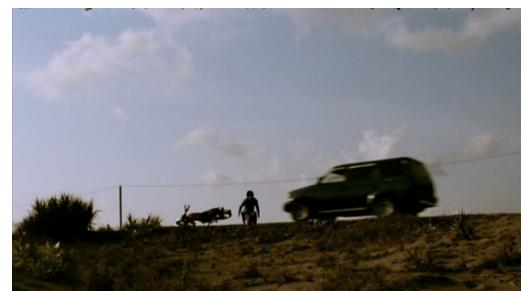

Di dalam teks Annisa menduga bahwa kecelakaan ini sebenarnya merupakan hal yang direncanakan oleh Syamsudin yang berniat membunuh Khudori (hal. 305) ini adegan yang tidak merujuk kepada teks sumber tersebut merupakan sisi problematik bukan hanya dari aspek struktur, tetapi juga tentang masalah pesan yang ditafsir berbeda oleh penonton yang notabene berkarakter heterogen. Bagi penonton demikian, situasi itu tampak bukan hanya dipahami sebagai penciptaan narasi baru, melainkan sebagai sumber konflik.

\section{Dramatisasi dan Oposisi sebagai Pemicu} Kontoversi

Alih media sastra ke film tidak berhenti pada soal teknis pengalihan struktur (dari verbal ke visual) dan juga transformasi aspek tematik (tema dan kisah yang ditafsir secara produktif oleh sutradara), tetapi tentu juga harus mempertimbangkan hal lain seperti apresiator atau penerima. Alih media, mau tidak mau mengalihkan juga ranah penerima, yakni dari pembaca ke penonton. Aspek psikologi, budaya, dan hal-hal lain yang melekat pada "kepembacaan" memiliki perbedaan dengan "kepenontonan".Pembaca, misalnya, adalah penerima yang secara psikologis telah mempersiapkan dirinya untuk masuk ke berbagai paparan yang panjang lebar dalam teks yang dibacanya. Pembaca novel sejenis $P B K S$ bisa dipastikan bukan pembaca yang tidak memiliki modal psikologis demikian.
Sementara itu, penonton secara umum adalah penerima yang berada di ranah publik yang heterogen, yang berkerumun, dan kecenderungan untuk mendapatkan hiburan lebih tinggi dari pada mencari dan menemukan makna lebih dalam dari film yang ditontonnya. Dengan demikian, bahasa visual film harus bersifat plural dan mudah dipahami.

Adegan pembuka film $P B K S$, yakni tentang seorang perempuan penunggang kuda dengan kepala ditutupi sorban dapat dibaca dalam kaitan dengan usaha memudahkan pemahaman sedemikian. Pada novel atau teks sumber, sosok dan adegan ini tidak ditemui. Pembaca hanya menemukan judul "perempuan berkalung sorban". Sosoknya sendiri hadir secara imajinatif di kepala pembaca bersangkutan. Di dalam film, sosok imajinatif ini lantas diwujudkan (divisualisasi) sehingga penonton (bukan pembaca) dapat langsung (dengan mudah) bertemu atau melihat sosok tersebut.

Selain kepalanya tertutup sorban, perempuan tersebut juga menunggangi kuda. Caranya menunggang kuda layaknya seorang prajurit yang sedang berperang. Kuda dan cara menunggangnya sedemikian juga tidak terdapat di dalam novel. Deskripsi terkait hal ini paling banter hanya ditemukan pada imajinasi Annisa kecil yang sering menyebut 
prajurit perempuan yang gagah berani pada masa Nabi Muhammad Saw. Perhatikan kutipan berikut:

“Kubayangkan kembali kisah lek Khudhori tentang Hindun binti Athaba yang mahir naik kuda dan menderap kian kemari di padang pertempuran. Ketika bayanganku sampai pada Putri Budur yang memimpin pasukan Raja Kamaruzzaman, dan para lelaki perkasa yang membeo seperti anak ayam di belakang ekor induknya" (El-Khalieqi, 2001, hlm. 7)

Dengan demikian jelas bahwa perempuan berkuda yang menyerupai prajurit perang di dalam film $P B K S$ merupakan visualisasi yang dilakukan sutradara atas imajinasi tokoh Annisa kecil. Visualisasi ini tentu saja juga merupakan eksekusi sutradara atas tafsirnya tentang sosok dan adegan demikian yang dibayangkan Annisa kecil. Jadi, sosok dan adegan tersebut merupakan imajinasi (sutradara) atas imajinasi (Annisa kecil). Upaya visualisasi ini, sekali lagi, memudahkan penonton untuk mengetahui dan memahami cerita secara keseluruhan.

Sekilas tampak bahwa proses ini merupakan hal biasa, yakni sesuatu yang memang niscaya dalam alih media verbal sastra ke media visual film. Akan tetapi, proses ini, bagaimanapun berbeda dengan, misalnya, visualisasi tokoh atau peristiwa tertentu yang dideskripsikan berdasar pada teks sumber. Tokoh atau deskripsi tersebut jelas ada di dalam teks sumber sehingga visualisasinya di dalam film dapat dikatakan sebagai transformasi (termasuk di dalamnya tafsir sutradara atas tokoh dan peristiwa yang dideskripsikan tadi). Pada kasus visualisasi sesuatu yang tidak terdapat pada teks sumber sebagaimana kasus di atas, istilah transformasi tidak tepat lagi digunakan. Di sini, yang terjadi adalah semacam proses penciptaan narasi baru. Dengan kata lain, sutradara menciptakan cerita baru yang tidak berdasarkan data tekstual pada novel. Acuan narasi baru tersebut sepenuhnya berada di dalam tafsir sutradara. Harus dipahami, memang, sebagaimana dikatakan Langer (1953, hlm. 59) bahwa di dalam proses penciptaan kreator tidak pernah mewujudkan atau memindahkan objek yang dilihatnya menjadi karya, melainkan mewujudkan (memvisualisasi) gagasan yang ada di dalam benaknya yang distimulasi oleh objek yang dilihatnya tadi. Namun, bagaimanapun, dua model penciptaan di atas, yakni transformasi dan penciptaan narasi baru tetap merupakan hal yang berbeda.

Jika dipahami dalam perspektif semiotika, proses tersebut bisa dikatakan sebagai semiotika penciptaan. Bertolak belakang denganilmu semiotika yang bergerak dalam ranah penafsiran tanda, semiotika penciptaan adalah proses penciptaan tanda (penandaan). Proses penciptaan tanda ini juga termasuk di dalamnya penafsiran tanda dengan tanda baru. Bagaimanapun, merujuk kepada Saussure (1990, hlm. 65-69), bahasa merupakan tanda, bahkan tanda yang paling sempurna. Judul "perempuan berkalung sorban" pada kajian ini, misalnya, adalah tanda bahasa. Tanda bahasa ini (penanda) merujuk kepada konsep tentang seorang perempuan yang 
mengenakan sorban dengan cara dikalungkan pada lehernya. Sosok dengan tampilan ini lantas akan menciptakan asosiasinya sendiri di benak pembaca. Di dalam film, asosiasi ini dieksekusi sutradara melalui visual yang hadir di hadapan penonton. Wujud ini jelas merupakan tanda baru. Inilah yang oleh penulis disebut sebagai penciptaan tanda.

Cara kerja penciptaan tanda tersebut pada praktiknya tidak pernah bisa dilepaskan dari konteks budaya dan asosiasi-asosiasi tentang sesuatu yang telah diyakini secara konvensional oleh masyarakat tertentu. Dengan kata lain, sutradara tidak mencomot begitu saja sebuah tanda untuk dirujukkan pada konsep atau sesuatu yang hadir pada teks sumber, baik secara verbal (sintagmatik) sebagai sebuah perwujudan atau deskripsi tekstual maupun secara asosiatif (paradigmatik) sebagai hasil tafsiran terhadap teks.

Penghadiran laut dan ombak pada film PBKS adalah contoh yang tepat untuk hal tersebut. Berbeda dengan sosok "perempuan berkalung sorban" yang hadir berbasis tanda bahasa pada teks sumber, laut dan ombak sama sekali tidak hadir, baik sebagai bahasa maupun imajinasi tokoh. Novel PBKS berlatar sebuah desa di pedalaman Jawa yang berjauhan dengan laut. Dengan demikian, laut dan ombak benar-benar ditambahkan sutradara sebagai tanda baru di dalam filmnya. Namun, tanda baru ini tidak dengan sewenang-wenang dipungut sutradara, tetapi melalui seleksi yang ketat. Bagaimanapun, sutradara tidak memilih hutan atau gunung yang secara geografis bisa dikatakan lebih dekat dengan tempat peristiwa cerita. Laut dan ombak, sebagai idiom yang juga telah dipilih oleh seorang penyair kenamaan angkatan Pujangga Baru, Sutan Takdir Alisyahbana (1908-1994), untuk menegasi karakter dusun dan tasik (danau) yang tenang, dipilih sutradara untuk mengasosiasikan kebebasan, pemberontakan, sekaligus keluasan pandang. Hal ini secara erat berelasi dengan tema cerita secara keseluruhan.

Selanjutnya, fakta visual lain yang menarik yang juga telah dihadirkan pada tabel di atas adalah adegan pertemuan intim Annisa dan Khudori di sebuah rumah kosong yang kemudian menimbulkan fitnah tentang perzinahan sehingga Annisa dan Syamsudin bercerai setelah sebelumnya dihujat penduduk di lingkungan pesantren. Sebagaimana telah dijelaskan, adegan ini tidak terdapat pada teks sumber. Di dalam teks sumber, kepulangan Khudori ke pesantren memang berkontribusi secara signifikan pada perceraian Annisa dengan Syamsudin. Tapi, proses perceraian mereka berlangsung secara normal, yakni melalui persiapan-persiapan tertentu, pertemuan dua keluarga, sampai terjadinya perceraian itu sendiri. Nyaris tidak terdapat konflik yang berarti pada bagian ini.

Lantas, mengapa sutradara memilih adegan tersebut? Merujuk kepada T. Jones, adegan itu dapat dikategorikan sebagai penyingkatan waktu penceritaan. Film adalah karya yang memiliki durasi pendek, sedangkan novel sebaliknya. Bagian perceraian yang dinarasikan dalam novel, untuk ukuran film bisa jadi bertele-tele: harus ada diskusi di lingkungan keluarga Annisa, 
menentukan siapa yang akan diutus sebagai wakil untuk pengurusan perceraian tersebut, pertemuan dengan keluarga Syamsudin, dan lain-lain menyebabkan kisah terlalu berbelit. Di dalam film, adegan-adegan tersebut sudah pasti membutuhkan waktu yang tidak sebentar. Oleh sebab itu, penyingkatan narasi dan waktu menjadi sangat penting.

Akan tetapi, di dalam film $P B K S$ pemilihan adegan tersebut tampak bukan sekedar untuk menyingkat narasi. Dikaitkan dengan penonton, film membutuhkan momen-momen peristiwa yang membuat penonton terhenyak dan tegang secara langsung bersamaan dengan peristiwa yang dilihatnya di layar. Klimak pada film membutuhkan keserentakan demikian; tidak seperti teks sastra. Pembaca sastra mungkin bisa mengikuti dengan sabar rentetan peristiwa hingga mencapai titik klimak, sementara penonton film cenderung sebaliknya. Film menuntut kesegeraan dan akselerasi tertentu, apalagi jika film tersebut memiliki keberpihakan kepada industri seperti juga $P B K S$, bukan film seni. Sebagai karya yang menempatkan gerak (baik gerak kamera maupun objek) pada posisi utama, film mementingkan efek kejut yang meminta perhatian penonton. Adegan pertemuan Annisa dan Khudori di rumah kosong diikuti dengan hujatan massa terhadap keduanya, ditambah dengan pingsannya (kemudian meninggal) ayah Annisa, dan keberanian Ibunda Annisa yang menantang semua orang untuk menghujat dan melempar dengan batu terhadap Annisa dan Khudori jika para penghujat itu merasa dirinya suci, menjadikan adegan tersebut menjadi penuh dengan efek kejut tadi. Adegan ini menjadi momen klimak yang sangat menegangkan.

Di samping itu, adegan tersebut juga mempertajam gagasan dasar atau aspek tematik cerita, yakni tentang pemberontakan seorang perempuan dari belenggu patriarkat berlatar ajaran agama yang kolot (melepaskan sorban yang melingkar di leher). Jika adegan perceraian dilakukan secara konvensional, narasi dimungkinkan akan terasa datar dan dengan itu konflik akibat pemberontakan tidak akan tajam. Hasilnya, adegan ini dipilih untuk mengeksplisitkan sisi ideologis cerita.

Dalam narasi berikutnya, setelah Annisa bercerai dan pergi ke Yogyakarta untuk melanjutkan studi, sutradara juga mengubah aktivitas Annisa di luar kampus. Di dalam teks sumber, Annisa dikisahkan sebagai penulis dan aktivis di bidang kepenulisan. Sedangkan di dalam film, predikat Annisa ditambah sebagai aktivis perempuan yang bergerak dalam wilayah ideologis perlawanan perempuan tentang kesetaraan gender. Annisa bekerja di LSM yang membela hakhak perempuan, terutama membela para istri yang menjadi korban kekerasan dalam rumah tangga (KDRT).

Aktivitas tersebut berhasil membangun relasi ideologis dengan adegan dramatis sebelumnya. Perjuangan Annisa dalam kesetaraan gender berhasil mengkontekstualisasi sekaligus mengaktualisasi tema cerita. Sebagaimana diketahui, persoalan gender merupakan gerakan yang terus-menerus diperjuangkan, baik di tingkat global maupun lokal, yang 
dengan demikian ia menjadi salah satu wacana dominan dalam kebudayaan. Maka ketika alur kisah $P B K S$ didudukkan dalam konteks ini-melalui aktivitas Annisa-PBKS menjadi aktual dan sekali lagi, menambah ketajaman konflik cerita. Bayangkan jika film PBKS mengikuti kisah dalam teks sumbernya, yakni hanya menjadikan Annisa sebagai seorang mahasiswa penulis dan seorang istri yang hanya suka memperbincangkan hubungan seks dan relasi gender laki-laki versus perempuan di kalangan temantemannya saja, sebuah kebiasaan yang lebih menyerupai gosip ibu-ibu. Jika ini dilakukan, PBKS dimungkinkan hanya akan menjadi kisah biasa-biasa saja.

Demikian strategi Hanung Bramantyo sebagai sutradara dalam pengalihmediaan, dari sisi tematis maupun bentuk. Pertanyaannya, sebatas hal tersebut dapat diterima dan dipahami penonton. Sebab, seperti telah disinggung, penonton film berbeda dengan pembaca sastra. Dengan demikian, dalam kaitan dengan kepenontonan adegan-adegan problematik, yakni yang mengusung tanda baru yang tidak merujuk kepada teks sumbernya menantang untuk ditelusuri. Penelitian terhadapnya, dengan demikian, tidak cukup hanya berdasarkan studi literatur. Studi empirik yang kami lakukan, dalam hal ini dengan mewawancarai secara tertulis 50 orang penonton sekaligus pembaca PBKS, menuntun ke arah diskusi yang menarik mengenainya. Berikut tabel resume hasil wawancara tersebut.

Tabel bagian pertama (I), sebagaimana dapat dibaca, menunjukkan pendapat penonton terhadap adegan pembuka film ini, yakni visualisasi seorang perempuan penunggang kuda dengan sorban melilit pada lehernya. Adegan ini, sebagaimana telah diuraikan, dapat ditelusuri pada teks sumbernya, yakni narasi mengenai Annisa yang sering berimajinasi tentang prajurit perempuan yang gagah berani. Oleh sebab itu, mestinya hal ini tidak menimbulkan masalah di kalangan penonton film, terutama yang telah membaca novelnya.

Namun, $85 \%$ penonton film sekaligus pembaca novelnya itu ternyata menolak adegan tersebut. Bagi mereka, adegan demikian lebih tepat disebut sebagai aktualisasi dan dramatisasi. Dapat diduga bahwa pandangan penonton tersebut terjadi mengingat PBKS sebagai judul novel dianggap lebih tepat diposisikan sebagai idiom sebab faktanya hal itu tidak ada di dalam cerita. Artinya, bagi penonton adegan itu tidak perlu divisualisasikan dalam bentuk sosok perempuan yang memakai sorban dengan cara mengalungkannya di leher. Visualisasi yang dilakukan sutradara atas hal tersebut dianggap lebih bertendensi untuk menciptakan dramatisasi sekaligus oposisi terhadap realitas masyarakat yang menjadi latar cerita, yakni masyarakat di Jawa Tengah. Meskipun menunggang kuda tidak dilarang untuk perempuan, faktanya hal itu bukan kebiasaan anak perempuan Jawa. Di samping itu, sorban bukanlah atribut perempuan muslim, melainkan untuk laki-laki. Dengan demikian, adegan tersebut dipahami sebagai dramatisasi. Lebih jauh, oposisi yang dibangun melalui visualisasi tersebut meniscayakan 
I. Tentang adegan pembuka dalam film yang tidak terdapat pada teks sumber.

\begin{tabular}{lc}
\hline \multicolumn{1}{c}{ Alternatif Tanggapan } & Respon \\
\hline $\begin{array}{l}\text { Wajar: sebagai tuntutan logis dari } \\
\text { media film yang berbeda dari } \\
\text { sastra }\end{array}$ & $5 \%$ \\
$\begin{array}{l}\text { Wajar: sebagai upaya sutradara } \\
\text { untuk membuat film menjadi } \\
\text { menarik }\end{array}$ & $8 \%$ \\
$\begin{array}{l}\text { Tidak wajar: sutradara membuat } \\
\text { oposisi dan dramatisasi terhadap } \\
\text { realitas }\end{array}$ & $85 \%$ \\
Tidak tahu & \\
\hline
\end{tabular}

II.Tentang karakteristik pemberontak Annisa kanak-kanak yang diperankan Abigail

\begin{tabular}{lc}
\hline \multicolumn{1}{c}{ Alternatif Tanggapan } & Respon \\
\hline $\begin{array}{l}\text { Wajar: dalam kehidupan nyata } \\
\text { terdapat pula anak dengan karak- }\end{array}$ & $25 \%$ \\
ter demikian & \\
$\begin{array}{l}\text { Wajar: sebagai upaya sutradara } \\
\text { untuk membuat film menjadi }\end{array}$ & $4 \%$ \\
menarik & \\
$\begin{array}{l}\text { Tidak wajar: sutradara membuat } \\
\text { oposisi dan dramatisasi terhadap } \\
\text { realitas }\end{array}$ & $70 \%$ \\
Tidak tahu & \\
\hline
\end{tabular}

III. Tentang aktivitas tokoh Annisa yang diperankan Revalina S.Tmeat sebagai aktivis LSM pembela perempuan, yang tidak merujuk kepada teks sumber

\begin{tabular}{lc}
\hline \multicolumn{1}{c}{ Alternatif Tanggapan } & Respon \\
\hline $\begin{array}{l}\text { Wajar: sebagai tafsir logis } \\
\text { sutradara atas penderitaan yang } \\
\text { dialami Annisa sebelumnya }\end{array}$ & $16 \%$ \\
$\begin{array}{l}\text { Wajar: sebagai upaya sutradara } \\
\text { untuk membuat film menjadi }\end{array}$ & $4 \%$ \\
menarik & \\
$\begin{array}{l}\text { Tidak wajar: sutradara membuat } \\
\text { oposisi dan dramatisasi terhadap }\end{array}$ & $78 \%$ \\
realitas & \\
Tidak tahu & $2 \%$ \\
\hline
\end{tabular}

terganggunya tatanan masyarakat yang menjadi latar belakang cerita tadi.

Pendapat serupa ditujukan juga pada karakter Annisa (kanak-kanak). Menurut $70 \%$ dari mereka, karakter pemberontak yang ditampilkan Annisa tidak wajar. Hanya 25\% saja yang menjawab bahwa karakter demikian bisa jadi ada di dalam kehidupan riil di masyarakat. Karakter ini, seperti juga telah disinggung sebelumnya, memang berbanding lurus dengan yang terdapat pada novel. Namun, jika sutradara memiliki keberanian melakukan tafsir yang berbeda bahkan ekstrem terhadap bagian lain, mengapa ia tidak melakukannya terhadap bagian ini. Dapat dipastikan bahwa karena bagian ini memang telah dramatik di dalam novelnya, pada film sutradara tidak merasa perlu mengubahnya. Hasilnya, tendensi sutradara untuk membuat oposisi dan dramatisasi atas realitas sebagaimana pendapat responden menjadi kian kuat.

Selanjutnya, kegiatan Annisa dewasa di Yogyakarta sebagai aktivis LSM yang membela hak-hak perempuan, juga dinilai penonton sebagai dramatisasi dan oposisi yang dilakukan sutradara. Sebagaimana tampak pada tabel ketiga, bagi $78 \%$ penonton aktivitas tersebut tidak wajar. Dapat dikatakan bahwa sutradara telah melakukan intervensi yang terlalu jauh terhadap teks sumbernya demi untuk mencapai efek dramatik.

Tiga kasus di atas menunjukkan bahwa penonton film berbasis alih media, yang sekaligus mengetahui kisah pada media asalnya (sastra), mengapresiasi film tersebut dengan cara membandingkannya 
pada kisah di media asalnya tadi. Penonton memiliki kesadaran untuk menilai sikap dan tindakan sutradara dalam menafsirkan teks sumber di dalam filmnya. Jika tafsir tersebut terlalu deviatif, penonton menilai sutradara memiliki tendensi tertentu di dalam penciptaannya, bukan hanya perkara bentuk atau pencapaian aspek artistik. Persoalannya, bagaimana deviasi sedemikian menimbulkan kontroversi, bahkan film PBKS kemudian dipaksa oleh kelompok masyarakat tertentu untuk ditarik dari peredaran. Imam Besar Masjid Istiqlal, Jakarta, misalnya, menyerukan agar masyarakat memboikot dengan tidak menonton film tersebut (Muslim Daily.net., 2016).

Dalam konteks karya seni, pesan dan makna karya memang tidak berlangsung dalam komunikasi praksis-meminjam istilah John Fiske (1992, hal. 2)-yakni komunikasi yang memungkinkan terjadinya kesalahpahaman. Beranalogi kepada Fiske, komunikasi seni berada di dalam ranah signifikasi, yakni berupa pertukaran tanda sehingga terjadi multi tafsir. Fiske menjelaskan sebagai berikut:

"It is concerned with how messages, or texts, interact with people in order to produce meanings; that is concerned with the role of text in our culture. It use term like signification, and does not consider misunderstandings to be necessarily evidence of communication failure-they may result from cultural differences between sender and receiver. For this school, the study of communication is the study of text and culture." (Fiske, 1992, hal. 2)
"Itu berkenaan dengan bagaimana pesan atau teks berinteraksi di antara para pelibat komunkasi dalam memproduksi makna; hal ini berkaitan dengan peran teks dalam kebudayaan. Dalam konteks ini digunakan istilah seperti pertandaan (pemaknaan) yang tidak memandang kesalahpahaman sebagai hal penting dari kegagalan komunikasi. Perbedaan pemaknaan terjadi hanya sebagai akibat perbedaan budaya antara pengirim dan penerima. Dalam mazab ini, studi komunikasi sama dengan studi teks dan kebudayaan".

Merujuk kepada pendapat tersebut, berbagai pihak dapat menafsir dan memberi makna karya film tanpa harus khawatir terhadap tafsir dan pemaknaannya. Sepanjang tafsirnya mengacu kepada metode tertentu yang sahih, tafsir selalu memiliki logika kebenarannya sendiri. Terlebih lagi jika tafsir tersebut dilakukan dalam ranah akademik atau merupakan kajian ilmiah berdasarkan pendekatan dan metode tertentu. Dalam tafsir ini, kebenaran tafsir tidak lain merupakan kebenaran metodologis, yakni sebatas mana seorang penafsir mampu mengoperasikan metode dan teori sebagai pisau analisis dan pijakan analisisnya tersebut.

Namun, dalam konteks masyarakat yang heterogen seperti Indonesia, persoalannya tidak demikian. Secara empirik, heterogenitas masyarakat Indonesia dalam banyak hal sering menimbulkan berbagai kontradiksi. Dalam masalah tertentu yang sensitif seperti menyangkut agama dan keyakinan, tafsir yang berbeda sering menimbulkan konflik 
horizontal. Hal ini, terutama, diakibatkan oleh sering munculnya kelompok dominan (mayoritas) yang mengklaim sebagai pemilik kebenaran. Suara-suara minor yang dianggap berbeda akan dengan segera mendapat tekanan dari kelompok dominan tersebut.

Tafsir sutradara film $P B K S$ terhadap beberapa adegan dan karakteristik tokoh pada novel yang dianggap penonton cenderung sebagai dramatisasi sebagaimana telah diuraikan di atas, sebenarnya hal itu sematamata terjadi karena yang ditafsir sutradara menyangkut permasalahan yang sensitif tadi, yakni persoalan seputar agama dan kehidupan di pesantren (lembaga pendidikan agama). Pembacaan penonton terhadap film $P B K S$, baik yang sebelumnya membaca novelnya maupun tidak, tampak lebih merupakan representasi dari suara yang telah menjadi pengetahuan umum (suara dominan) masyarakat. Deviasi yang dilakukan sutradara di dalam film dianggap telah keluar dan menyinggung suara dominan tadi.

Di dalam konteks masyarakat demikian, sifat film sebagai karya seni yang sejatinya berada di dalam ranah komunikasi signifikasi sebagaimana pendapat Fiske di atas, menjadi tidak kokoh. Dengan kata lain, film cenderung dipahami sebagai teks yang bermakna tunggal. Di situ, film PBKS tidak diberi ruang bagi penafsiran lain, kecuali bahwa ia telah menyinggung suara dominan di masyarakat. Lebih jauh, dalam kasus lain bahkan tidak jarang masyarakat mengabaikan teks seninya itu sendiri. Aspek yang sering dinilai justru penciptanya (sutradara, pengarang, musisi, dan seterusnya) atau aspek tertentu saja yang terdapat pada teks. Pada masa pemerintahan orde baru (1966-1998), pelarangan terhadap buku-buku karya Pramoedya Ananta Toer, misalnya, bukan karena isi yang dikandung karya-karya tersebut, melainkan karena aktivitas Pram yang anti orde baru. Sejak reformasi 1998, perilaku refresif rezim orde baru tersebut tampak diambil alih-lebih tepat diwarisi-oleh kelompok-kelompok dominan tertentu. Pada 2016, pementasan teater (monolog) karya penyair Ahda Imran di Institut Francais Indonesia (IFI) di Bandung, nyaris dibatalkan karena diprotes sekelompok masyarakat tertentu yang menganggap pementasan tersebut bertentangan dengan agama dan ideologi Pancasila. Menurut catatan Wulandari (2016), ketika dilakukan musyawarah antara kru teater dengan kelompok tersebut, diketahui bahwa kelompok yang memprotes tersebut ternyata tidak membaca naskah teater tersebut. Protes dilakukan karena teater tersebut bercerita tentang Tan Malaka, tokoh sejarah yang dianggap menganut faham yang bertentangan dengan Pancasila, yakni komunis.

Dalam sosiologi penonton demikian, sekali lagi, film $P B K S$ hadir. Oleh sebab itu, kontroversi tidak bisa dihindari. Kajian kami terhadap fakta kontroversi ini menghasilkan rumusan bahwa dalam film alih media, posisi sutradara bukan semata-mata kreator yang dari sudut pandang estetik dan teoretik menafsir teks sumber (novel), melainkan juga penafsir yang tidak dapat melepaskan dirinya sebagai anggota masyarakat yang juga memiliki pemahaman tentang teks sumber. Pemahaman masyarakat ini 
tidak dapat menghindar dari suara-suara dominan di dalam masyarakat tersebut. Sutradara atau kreator, mau tidak mau, harus mempertimbangkan suara dominan yang telah menjadi pengetahuan umum masyarakat. Strategi memahami sosiologi penonton yang heterogen menjadi sangat penting agar karya dapat sampai kepada penonton, dalam arti tidak ditarik dari peredaran.

\section{PENUTUP}

Dari analisis di atas dapat disimpulkan beberapa hal sebagai berikut. Ditemukan bahwa dalam kasus film $P B K S$ pergeseran dalam adaptasi terjadi lebih pada aspek bentuk (struktur), sedangkan aspek tematik (isi) tetap mempertahankan atau sesuai dengan yang terdapat dalam teks sumbernya. $P B K S$, baik sebagai novel maupun film berkisah tentang pemberontakan seorang tokoh perempuan yang terbelenggu dalam kuasa laki-laki dengan latar belakang ajaran agama (Islam) ortodok.

Namun, meskipun tema film tetap mempertahankan tema novelnya, pergeseranpergeseran pada lapis bentuk (struktur) menyebabkan atmosfer cerita menjadi berbeda. Sebagai film, PBKS menghadirkan konflik antar tokoh yang bertegangan dalam cerita menjadi semakin tajam. Di hadapan penonton yang juga membaca novelnya, konflik-konflik dalam film dinilai sebagai upaya sutradara untuk menciptakan oposisi dan dramatisasi yang berlebihan.

Kenyataan itu sekaligus menyebabkan film $P B K S$ mengirim tendensi pesan lain jika dibandingkan dengan novelnya meskipun gagasan dasarnya sama. Jika pada novel kesan yang tertangkap adalah perjuangan tokoh melawan ketidakadilan lingkungan yang dilandasi sikap emosional, pada film kisahnya menjadi konseptual, ideologis, bahkan politis.

Fakta itulah yang menyebabkan PBKS menjadi kontroversi di masyarakat. Berbagai kritik dan hujatan terhadap $P B K S$ terjadi setelah karya ini dialihmediakan menjadi film. Hal ini terjadi karena jika karya sastra cenderung dinikmati pembaca (apresiator) di ruang-ruang tertutup, film mengeluarkannya dari ruang tersebut menunjuk ke ruang publik yang lebih luas dan terbuka. Situasinya menjadi semakin tidak kondusif ketika di dalam masyarakat terdapat kelompokkelompok tertentu yang dominan yang dengan dominasinya mengklaim kebenaran sebagai hanya milik kelompoknya. Topik-topik sensitif seperti yang menyangkut masalah agama dan keyakinan umumnya sangat rentan terhadap konflik ketika ia diangkat ke ruang publik dalam bentuk karya seni.

Hal ini menunjukkan bahwa pengalihmediaan menuntut pertimbanganpertimbangan di luar hal teknis (faktor intrinsik) pengalihmediaan itu sendiri. Faktor ekstrinsik, antara lain aspek psikologi dan sosio-kultural masyarakat harus menjadi bahan pemikiran dan pertimbangan para pencipta film berbasis alih media sehingga dengan itu bisa diputuskan sebatas mana misalnya, deviasi dan distorsi atas media sumber dapat dilakukan. Pertimbangan ini menjadi kian penting dalam konteks masyarakat yang heterogen seperti Indonesia, 
yang dalam banyak hal belum sepenuhnya dapat menerima perbedaan. Di Indonesia, teks (karya seni) tidak pernah bisa berdiri sendiri (otonom) sebagai entitas yang dapat ditafsir dengan bebas. Sisi-sisi pragmatik dan sosiologis sering lebih penting daripada karya itu sendiri.

\section{Daftar Pustaka}

Buku

Abrams, M.H. (1980). The Mirror and The Lamp, Romantic Theory and The Critical Tradition. London. Oxford University Press.

Berger, John. (1977). Ways of Seeing.USA. Penguin Books.

El-Khalieqi, Abidah.(2001). Perempuan Berkalung Sorban (novel).Yogyakarta: Yayasan Kesejahteraan Fatayat.

Eco, Umberto. (1979). A Theory of Semiotics. Bloomington.Indiana University Press

Fiske, John. (1992). Introduction to Communication Studies.Lindon and New York.Routledge.

Jones, Mathew Thomas. (2008). Found in Translation: Structural and Cognitive Aspect of The Adaptation Comic Art to Film. Philadelphia, Pennsylvania : Temple University Press.

Langer, Suzane. K. (2006). Problematika Seni, terjemahan F.X Widaryanto. Bandung: Kelir

(1953).Feeling And Form. A Theory of Art Developed From Philosophy in a New Key. New York: Charles Scribner's Sons.

Leittch, Thomas. 2007. Film Adaptation \& Its Discontents, From Gone With The Wind to The Passion of the Christ. Baltimore. The Johns Hopkins University Press.

Saussure, Ferdinand de.(1990). (second impression).Course in General Linguistics (translated and annotated by Roy Harris) .London: Gerald Duckworth \& Co.Ltd.

Tim Pengajar Tata Tulis Karya Ilmiah, Institut Teknologi Bandung. (2015). Metode Penulisan Ilteks. Bandung: Kelompok Keahlian Ilmu Kemanusiaan Institut Teknologi Bandung.

\section{Jurnal}

Saidi, Acep Iwan. (2011). "Transformasi Narasi Verbal Karya Sastra ke Narasi Film". Jurnal Panggung, 21 (1), 10-19

\section{Website}

Turmudi, Endang (2015) dari situs http:// www.cnnindonesia.com. Diunduh pada 23/01/2015.

“Daptar Film Indonesia Yang Diangkat dari Novel Tahun 2013". Diunduh pada 18 Mei 2016 dari http://indosinema. com/2013/02/daftar-film-indonesiayang-diangkat-dari-novel-ditahun-2013/

"Daptar Film Indonesia Yang Diangkat dari Novel Tahun 2014". Diunduh pada 18 Mei 2016 dari http://indosinema. com/2013/12/daftar-film-indonesiayang-diangkat-dari-novel-tahun-2014/

"Imam Besar Istiqlal Serukan Boikot Film Perempuan Berkalung Sorban". Diunduh pada 15 Mei 2016 dari http:// www.muslimdaily.net/entertainment/ imam-besar-istiqlal-serukan-boikotfilm-perempuan-berkalung-sorban. html\#

Wulandari, Catur Ratna (2016). “Monolog Tan Malaka Dibubarkan FPI". Diunduh pada 18 Mei 2016 dari http// www.Pikiran Rakyat.com /bandungraya/2016/03/23/364822/monolog-tanmalaka-dibubarkan-fpi 